\title{
Factors Affecting Customer Satisfaction from the Status of Banking Services "System Service, Exchange and Behavior", Based on Systra (Case Study: Keshavarzi Bank of Kermanshah)
}

\author{
*Akbar Veismoradi \\ Department of Accounting, Payame Noor University, I.R of IRAN \\ *Corresponding Author Email: veismoradi2462@gmail.com \\ Peyman Akbari \\ Department of Management, Payame Noor University, I.R of IRAN \\ Younes Abbasi \\ Department of Accounting, Payame Noor University, I.R of IRAN \\ Seyed Mohsen Madineh \\ Department of Accounting, Payame Noor University, I.R of IRAN
}

Doi:10.5901/mjss.2015.v6n5s2p522

\begin{abstract}
In today's competitive world, without a doubt the most important assets of any organization customers from manufacturing, or services are considered. Customer care and satisfaction is what he is, that is to compete at the global level. Large investment banks to diversify products and services, and improve the quality and good will doing service, all with the aim to satisfy existing customers and new customers is to prevent deterioration. This study examines the factors affecting customer satisfaction, the state banking "service system, and conduct exchange", based on the model's Systra. For this reason, in this study used a questionnaire that, among 384 clients of the Keshavarzi Bank of Kermanshah, randomly distributed. By three professors of validity, and reliability with Cronbach's Alpha was 0.764 . Methods Descriptive is a survey. The period under review, is the first half of 2015. T-test to test hypotheses, and the Friedman test for the factors affecting customer satisfaction, the status of banking services, from the perspective of the customer. Results 4-1 hypothesis that the influence of four factors (The quality of service system, the quality of service devices, the accuracy of the exchange service, the quality of treatment services), customers using electronic banking services, Keshavarzi banks, to confirm. In H5 most important factors on the situation of banking services, customer satisfaction, from the perspective of customers, service system, is.
\end{abstract}

Keywords: four factors (Systra model), customer satisfaction, electronic banking.

\section{Introduction}

Today, information and communication technology, has overshadowed all sectors of societies. Without a doubt, in the near future, the success of the communities that would be the concept of speed and ease of information and communication, are found in the well. Features of ICT, not only the emergence of a new perspective in the banking system, on how to provide the services required by our customers, but also new horizons in the field of modern banking services, and development of new ways of delivering traditional banks opened, so that the future of banking, based on a benchmark of success in the information technology. Undoubtedly, the use of information and communication technology, one of the tools to increase the efficiency of the national economy. Launch e-commerce in terms accelerate transactions, enhance competitive position in the region, providing security and confidence to the business, reduce costs, increase exports and other economic functions. Considering the growing trend of global economic trends, e-commerce, despite its complementary components, such as e-banking and e-government, as an undeniable necessity. E-banking, using electronic communication technology and knowledge, apart from communication and interaction with e-commerce and egovernment, to improve the banking services fast and cost-effective for customers with large application (Poor- 
Mohammadi, 2008). The competitive situation of the banks, and to increase community awareness and changing needs and demands of customers, which resulted from the increasing development of information and communication technologies, the development of electronic banking, has made a commitment. The banks and financial institutions, always trying to fulfill the needs and demands of our customers. Bank to retain customers and herself Loyal the first level, and attract new customers trying to outdo the other banks by offering differentiated services and so on. Since the preservation and survival of the organization, customer satisfaction, organizations that are successful in this way, in addition to maintaining our customers, reduce costs, attract new customers, repeat business away from competitors, and a competitive advantage, customer-focused organization, they acquire (Karimi, Hasan Abad, 2008). Today, customer satisfaction is not enough though, and institutions such as banks should not rely on their customer satisfaction, and not only think about the needs of existing customers because the bank has been successful in providing modern banking services that, have been able to understand the future needs of customers. They have to be convinced that they can do the needs assessment diagnosis clients, customers will need in the future, what kind of service, and in fact one step ahead of their customers, and their customers become loyal. The aim of this long-term relationship with the customer, in order to obtain long-term resources for the bank. So today the bankers to their customers in the mirror and try to see, in the absence of time, for banks to compete harder and more complex, understanding the needs of their target customers, and that customers do They are full of content (Shamloo, 2010). The fact is that, to stay competitive in the market and being part of the market, in the long run we need loyal customers, and other important prerequisite to gain their trust, will not be achieved. Banks today are well aware of this issue, to sustain their high level of customer satisfaction, it will be necessary, and this time will be realized, which can offer customers new services and up to date, and to know the services customers deals, to what extent will their consent, and which type of bank able to serve, to attract more satisfied than competitors.

\section{Statement of Problem}

Although it is true that we have ever before, we live in an era of change, but the dominant social structures often prevent the dissemination of innovations. Between what is human and what is effectively applied in practice, should be reduced, to minimize the distance you need to know how to get new ideas from the source of potential emissions be, and what factors affect the acceptance of these innovations. One of the innovations, the extensive development of information and communication technology, has experienced significant growth in the volume of business mail. According to Forrester Research, e-commerce during the period 2002-2006, an average of more than 58 percent growth, and from 2293 billion in 2002 to more than 12,837 billion in 2006 was over. The banking industry today is changing rapidly, with the development of the international economy and competitiveness of the markets, the banks have also been affected, the main force in this area of technology that would break down regulatory barriers, geographical and industrial, and has created new products and services (Vatan Doost, 2010). Electronic banking, which includes all electronic channels, customers to access their accounts, transfer funds between accounts and, or pay their bills, which they use. These channels include the Internet, mobile phone, digital TV, and ATM (Liu et al., 2003). The interest large banks in developed countries and developing countries, to provide banking services through electronic channels, and the development banks and financial institutions are Virtual increased competition in the banking industry, to so that other banks also tried to develop different approaches have emerged electronic banking. With the introduction of Iran's membership in the WTO, and the entry of foreign competitors into the financial base of the country, Iranian banks also need to develop their services in line with technological changes, and the other before the introduction of any new services, should economic research mentioned services, new services adapted to the needs of society and that, whether the system can service, to provide good customer, take place. In developing countries, the bank is likely to review the services provided by the banking system in developed countries, the duplication of services, and the lack of research and studies required for such services, as a partial offer to their customers. Obviously, in the absence of a system of electronic banking customers, offering such services will fail (Aladwani, 2007). Unfortunately, given the importance of this issue, so far no research has been done about it, identify the factors that cause consumers plan to use a new technology, such as the use of electronic banking services is, is important because it identifies These factors help the bankers, and their marketing strategies, to promote new forms of electronic banking systems to be used (Seyed Javadin, 2005). Therefore, in order to identify factors affecting clients of internet banking services, and the lack of adequate studies and research in this field, this study examines the use of model Systra, in the field of electronic banking in the Keshavarzi Bank of Kermanshah deals . According to this model, the factors affecting customer satisfaction electronic banking services, including systems, devices, services, health, trade services, behavioral services system in the form of four hypothesis were presented. 


\section{The Importance and Necessity of Research}

Set of banking services, and how to change in our country in recent years, development has been relatively strong, but banks have failed new banking services, such as what is customary in the world, the public supply. Today, the world is wide banking services. Types of credits, consumer credits and credit cards, and smart planning, retirement funds, investment services, financial consulting services, issuance of insurance policies, safe deposit boxes, electronic funds transfer, foreign exchange transactions, credit for international trade In general, a set of banking services, is so broad that bank to bank department store or chain store financial institutions have turned. For example, it is necessary to note, Deutsche Bank offers banking services in Germany for at least three item, whereas in most of the forty types of service are not going to, maybe one of the reasons for the failure to understand the impact of new banking services, on customers of the banks, and that the needs and requirements of today's society require that more activities and resources is on basic payment. (Shamloo, 2010). Marketing scholars and practitioners can interpret these results as helping to justify expenditures on brand and customer related marketing activities that create such long-term brand relationships with their consumers. (Taleghani et al., 2011) Banks as financial arteries of society, can play a role in daily life, and the speed, accuracy and reliability of their performance, a great impact on the efficiency of the economic system, and the implementation of the subject, describes the current situation of human life and the wants and needs of their activities, need the development and launch of new banking and modern banking services to increase customer satisfaction, and profit is through service fees. Thus, the importance of customer satisfaction for banks and their trust through high-speed and secure services on the one hand, and also to keep pace with the developments and global changes, to develop business and create competitive advantage by providing new services bank in the region, and reduce many of the costs for banks, expansion of electronic banking, and study of the importance of this issue is essential. As Dominique Turpin doctor, found that customer satisfaction, the first mission and priorities outlined by senior management, and the involvement and continuing commitment of top managers of companies, the issue of customer satisfaction as a prerequisite for success is taken into account. Banks and banking industry, according to the type of services offered, and to consider the close relationship that exists between the organization and its customers, customer care is very important. Because customers only source of income for the organization and the bank, and without them there would be organizational. So from the time of the service offered to the customer, have ideas, tastes and desires, he fully considered and addressed. Given the importance of the customer's ideas led to the devotion and loyalty to the organization and its cause, not only in the form of customer satisfaction there, but she knows her part of the organization. This satisfaction is the key to the success of the bank. For these reasons the banks in order to attract new customers and satisfying their existing customers, steps are (Golchinfar, 2002). Given the importance of customer satisfaction, and knowing that the cost of attracting a new customer is between five to eleven to keep an old customer, and the loss of losing a customer, in order to lose one hundred customer the newly privatized state-owned banks, and private have accepted that customer satisfaction is a prerequisite for all the success of the bank, and compete for first place in customer satisfaction among the country's banks, affirms the importance of customer satisfaction, In this industry, the continuation of this subject and it is essential to provide quality service and innovative, determined to serve the new bank, the impact on customer satisfaction, and the success and satisfaction in providing electronic banking services, with clients Keshavarzi Bank of Kermanshah, using what is Systra. In this study, to find the answer to this important step towards customer satisfaction, and create new services based on science, and in line with modern technological developments, it will be removed.

\section{Literature}

Research related to customer satisfaction, electronic banking services were as follows. The internal investigation to the investigation by Mr. Moghli, Seyedjavadin and Sarmad Saeedi was said, and international research, including research by Teo and Lin, Krauter and Faullant, Clik, point a. But according to the survey that has been conducted has had a study that aims to determine the factors affecting customer satisfaction, the state banking "service system, exchange and behavioral" Systra Model (Case Study: Bank Agriculture Kermanshah Province), have been taken. Therefore, we reviewed above, the study and the study of its type, though in terms of methodology, the process may, similar to the investigation, but the whole purpose is very different. The theoretical framework of this study, the most important and influential variables relevant to identify a research problem, and according to the findings of previous research, the relationship between variables is as follows. Moghli (2007), in a study to investigate the factors influencing the adoption of electronic banking, the bank customers to pay the city. Side of that, ease of use, usefulness and trust of customers, the acceptance of electronic banking is effective. Seyedjavadin (2006), examines the factors influencing customers to use the 
Internet banking services (Case study Saman bank), using the Technology Acceptance Model Davis. He found that the Technology Acceptance Model, the model used for describing the behavior of internet banking services, and the perceptions of the ease of use of internet banking services, and the usefulness of these services, as well as "selfefficacy" one in use computers, with the intention of using these services is directly related. Teo and Lin (2009), the acceptance and rejection of electronic shopping, with a sample of 141 member companies Singaporean began. He found that the size of the company, senior management support, indirect benefits perceived positively and significantly impact your business partners, the acceptance of electronic purchase, and type of industry no connection with the adoption of electronic shopping, shows . Krauter and Faullant (2008), the acceptance of electronic banking, on behalf of clients in Australia. He found that trust to the Internet, the risk perception and attitudes toward using internet banking is effective. Click (2008), the acceptance of electronic banking, payments from customers in Turkey. He found that perceived usefulness, and perceived ease of use determinants of customers' attitudes toward using internet banking is. According to research records, as well as conceptual models, the assumptions of the study are as follows:

Hypothesis 1: The quality of service system, as one of the factors affecting satisfaction, the quality of banking services among clients of the Keshavarzi Bank of Kermanshah, has a significant positive effect.

Hypothesis 2: the quality of service devices, as one of the factors affecting satisfaction, the quality of banking services among clients of the Keshavarzi Bank of Kermanshah, has a significant positive effect.

Hypothesis 3: the accuracy of the exchange service, as one of the factors influencing satisfaction with the quality of banking services among clients of the Keshavarzi Bank of Kermanshah, has a significant positive effect.

Hypothesis 4: the quality of treatment services, as one of the factors influencing satisfaction with the quality of banking services among clients of the Keshavarzi Bank of Kermanshah, has a significant positive effect.

Hypothesis 5: the effect of each of the four factors, the Keshavarzi Bank of Kermanshah electronic banking among customers, are the same.

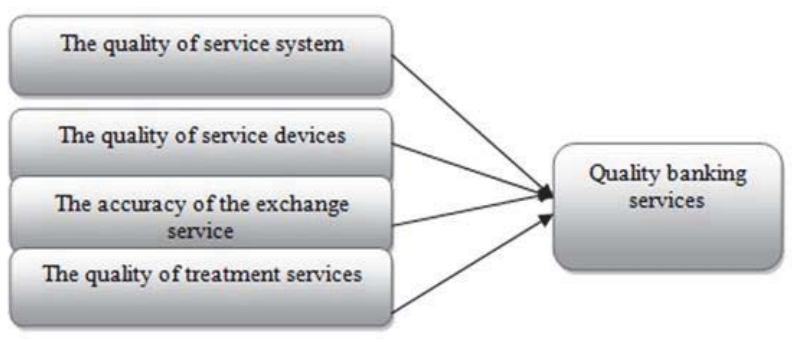

Figure 1. Conceptual Model of Research

\section{Research Methodology}

The research for the purpose of the application, and the data collection methods, descriptive survey of correlation. The study population consisted of 384 people, is an employee of the Keshavarzi Bank of Kermanshah province, randomly, using as an example for the first half year of 2015 were selected. The questionnaire, Systra is used. Scale questionnaire measuring range that was designed five options, the scoring of questions, from the 1 to the 5 , is calculated. To confirm the validity and reliability, gauges, respectively, of the professors, and Cronbach's alpha coefficient (0.814) is used. And to analyze the data, the (One-Sample Test) T-Test and Friedman test, at 0.95 , is used, if it is confirmed ${ }^{P-v a l u e}<5 \%$ the hypothesis $\left(\mathrm{H}_{1}\right)$, and otherwise If $\left(\mathrm{H}_{1}\right)$ is rejected.

Table 1: Descriptive statistics of the study

\begin{tabular}{|c|c|c|c|c|}
\hline \multicolumn{4}{|c|}{ Group (percent) } & \multirow{3}{*}{$\begin{array}{l}\text { Property } \\
\text { Sex } \\
\text { Age }\end{array}$} \\
\hline \multicolumn{2}{|c|}{ Woman $(0.40)$} & \multicolumn{2}{|c|}{$\operatorname{Man}(0.60)$} & \\
\hline Over 55 years $(0.04)$ & $45-55$ years $(0.11)$ & $35-45$ years $(0.29)$ & $20-35$ years $(0.56)$ & \\
\hline PhD and higher (0.5) & Master of $\subseteq$ & ience $(0.30)$ & Bachelor (0.65) & Academic degree \\
\hline Over 20 years $(0.014)$ & $11-20 y$ & $\operatorname{rrs}(0.26)$ & $1-10$ years $(0.60)$ & Experience \\
\hline
\end{tabular}




\section{Analysis of Results}

Table 2: T-Test of One sample

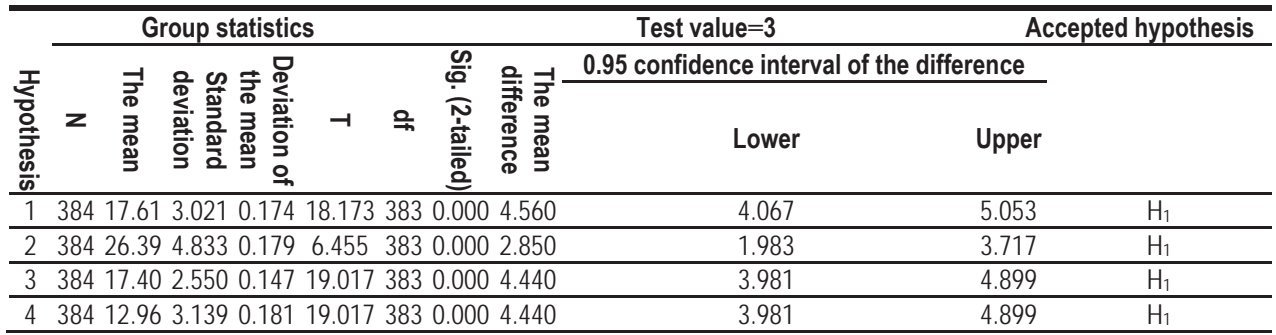

The results of the first hypothesis, suggests that: The quality of service system, as one of the aspects that influence satisfaction, the quality of banking services among clients of the Keshavarzi Bank of Kermanshah, given the significant level. (0.000), and the level of acceptable error (0.05), and 0.95 are effective, and this represents the hypothesis $H_{1}$, indicating the effectiveness of the agreement is approved.

The results of the first hypothesis, suggests that: the quality of service devices, as one of the aspects that influence satisfaction, the quality of banking services among clients of the Keshavarzi Bank of Kermanshah, given the significant level. (0.000), and the level of acceptable error (0.05), and 0.95 are effective, and this represents the hypothesis $\mathrm{H}_{1}$, indicating the effectiveness of the agreement is approved.

The results of the first hypothesis, suggests that: the accuracy of the exchange service, as one of the aspects that influence satisfaction, the quality of banking services among clients of the Keshavarzi Bank of Kermanshah, given the significant level. (0.000), and the level of acceptable error (0.05), and 0.95 are effective, and this represents the hypothesis $\mathrm{H}_{1}$, indicating the effectiveness of the agreement is approved.

The results of the first hypothesis, suggests that: the quality of treatment services, as one of the aspects that influence satisfaction, the quality of banking services among clients of the Keshavarzi Bank of Kermanshah, given the significant level. (0.000), and the level of acceptable error (0.05), and 0.95 are effective, and this represents the hypothesis $\mathrm{H}_{1}$, indicating the effectiveness of the agreement is approved.

Table 3: that, Friedman

\begin{tabular}{|c|c|c|c|c|c|c|c|}
\hline Significance level & df & $x^{\wedge^{2}}$ & 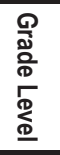 & $\mathrm{N}$ & 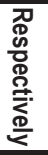 & Four Factors (Systra model) & Hypotheses \\
\hline \multirow{4}{*}{0.000} & \multirow{4}{*}{3} & \multirow{4}{*}{1282.1} & 1.48 & 384 & 1 & The quality of service system & \multirow{4}{*}{ 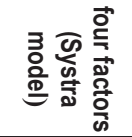 } \\
\hline & & & 1.84 & 384 & 2 & the quality of service devices & \\
\hline & & & 3.35 & 384 & 3 & the accuracy of the exchange service & \\
\hline & & & 4.10 & 384 & 4 & the quality of treatment services & \\
\hline
\end{tabular}

According to Table (3) that, Friedman test shows, the four factors in the Keshavarzi Bank, according to the priorities of the 4 are as follows:

Keshavarzi Bank of service system, service devices, exchange service, treatment services

\section{Interpretation of Findings}

As shown hypothesis of this study was approved: The verification of these assumptions are in line with research by scholars Moghli (2007); Seyedjavadin and Yazdani (2006), Teo and Lin (2009), Krauter and Faullant (2008) and Click (2008), have been conducted. 


\section{Practical Suggestions}

Proposals have been presented in two parts, the first part consisting of proposals for research applications, to improve electronic banking services, Keshavarzi Bank among customers, and the second part contains recommendations for future research.

Practical suggestions First hypothesis:

1. The bank employees have to talk to customer demands their attention.

2. Advising customers by bank employees shall be such that it will be useful for the customer.

3. The Bank shall in due course, to its own commitments.

4. Banks should quickly to the needs and demands of customers, answer.

5. The bank employees must have the knowledge and skills necessary for the work to do.

6. Bank facilities should be such that the client is safe.

7. Bank for banking, use of the latest technologies.

8. Access to the bank by the customer, through the phone or the Internet.

The second hypothesis practical suggestions:

1. Bank ATMs, customers should feel that trust.

2. The Bank shall act in providing services that meet the needs of the customer through your bank ATM, remove. The third hypothesis practical suggestions:

1. Banking transactions (delivery of money, bills, etc.), the Keshavarzi Bank of accuracy is necessary.

2. How do you evaluate the incidence of mistakes and errors in the bank, the bank must lower its Practical suggestions fourth hypothesis:

1. Banks should employ the staff is courteous. Polite behavior at work so employees, customers receive

2. Bank staff to their desire to help and serve the same customer.

\section{Proposals for Future Research}

1. The researchers recommended, using the same variables of the study in the future with more banks, and in the course of further study, using the methodology of the research done to validate and the estimated model, the study added.

2. The researchers recommended, using the same variables of the study was to compare, in one of the country's banks do, and the results of that study to compare results.

3. The researchers recommended, using the same variables of the study to more banks more provinces, as do a comparison, and the results of that study to compare results.

4. The researchers recommended the use of variables in this study, this study is to compare the relationship or, according to other models, such as models in this area Davis, and ... The country's banks do, and the results of that study to compare results.

5. The researchers recommended, using the same variables of the study, the influence of factors such as gender and age, on their electronic banking model.

\section{Acknowledgement}

This article is part of project grant title: Factors affecting customer satisfaction from the status of banking services "System Service, Exchange and behavior", based on Systra (Case Study: Keshavarzi Bank of Kermanshah) the cost is paid by Payame Noor University Islamic republic or Iran.

\section{References}

Aladwani MA., (2007). Online banking: a field study of drivers, development challenges, and expectations ". IJIM, 21 (2007), PP. 213225.

Clik, H. (2008) .What determines Turkish customers' acceptance of internet banking? ", International Journal of Bank Marketing, 26 (5), pp. 353-370

Golchinfar, S., (2002) Factors affecting the welfare of the Bank's customers. Master Thesis of Tehran University School of Management, $p 13$

Krauter S. G., Faullant R. (2008). Consumer acceptance of internet banking: the influence of internet trust, International Journal of Bank Marketing, 26 (7), pp. 483-504 
Karimi Hasan Abad, Z., (2008). Evolution of electronic banking income, the modern banking., E-Faba, 1 (1), p. 34

Lu J, Yu CS, Liu CE, Yao, J. (2003). Technology Acceptance Model for wireless internet. ENAP, 13 (3), PP 56-72.

Moghly, A., (2007). Acceptance of electronic banking, the bank customers in Shiraz. Journal of Management Sciences in Iran, the second No. 7, p. 81

Poormohammadi, S.H., (2008). The future of banking. Tehran: Faba Center, No1

Seyedjavadin, S.R and Yazdani S., (2005). Factors influencing customers to use the Internet banking services (Case Saman) .journal of knowledge and management, 70 (18), p. 45

Shamloo M., (2010). Marketing and customer in the bank. Tehran: Publication of Andisheh Mana, third edition, pp. 11, 12

Taleghani, Mohammad., Samadi Largani, Mahmood., Mousavian, Seyyed Javad. (2011). "The investigation and analysis impact of brand dimensions on services quality and customers satisfaction in new enterprises of Iran", Contemporary Marketing Review, Vol. 1(6) pp. $01-13$.

Teo.t.s.h, Lin.h. (2009). Adopters and non-adopters oe-procurement in Singapore: An empirical study", omega 37, pp. 927-987.

Vatandoost, T., (2010) . essay effects of the spread of electronic banking, the level of customer satisfaction in the Bank Refah, Kano model. MA Thesis of Business Administration Islamic Azad University of Kermanshah, pp. 3, 25, 30 